\section{Cumulative Temperatures}

In reference to my letter upon the above subject, which was published in your columns of February $2 \mathrm{I}$ last, I have received from Prof. de Candolle, of Geneva, a communication dated March Ir, in which he calls attention to the fact that in his "Géographie Botanique raisonné," which was published as far back as the year 1855 , he recorded the suggestion (made by him. self some ten years previously) of the employment of an uncompensated pendulum fitted with a suitable registering apparatus for the determination of cumulative temperatures in connection with the application of meteorology to agriculture and to the geography of plants.

In the above work (vol. i. pp. $5^{8}$ and 59 ) the following passage occurs :-

"Les chiffres les plus importants à connaître pour les applications de la météorologie ì l'agriculture et à la géographie botanique sont, pour chaque localité, les sommes de température au dessus de $+1^{\circ},+2^{\circ}$, de $+3^{\circ}$, etc., par année, saison, mois ou fraction de mois.

"Pourrait-on obtenir ces valeurs directement par un instrument spécial, qui dispenserait de recourir ì des calculs compliqués, souvent impracticables, dans le système actuel des observations métécorologiques? C'est une question que je scuusets aux physiciens. Elle m'a préoccupé depuis longtemps, mais je suis loin de posséder les conmaissances thioreticques et pratiques nécessaires pour arrivir it une solution. J'entrevois la possibilité de construire cleux sortes d'instruments qui rúponiraient aux conditions désirćes; je les mentionne sans pouvoir incliquer les détails d'exúcution.

"L'un de ces instruments serait la pendule-thermonictre de M. Edmond Becquerel, modific de telle sorte que les battements par une température inférieure it $0^{\circ}$, ou ceux infúrieures it $+I^{\circ}$, it $+2^{\circ}$, etc., ne seraient pas comptés."

"Un autre ssstime serait celui de thermometrographes marquant les températures supćrieures ì tel ou tel degré, et seulement celles-là."

To this the following foot-note was added:--m" Il y a plus de dix ans je fit des démarches anprès de denx astronones, M. Gautier, à Genève, et M. Arago, à Paris, pour appliquer la pendule à la mesure des températures. Je proposais une pendule aussi dilatable que possible sous l'action de la température et un ompteur adapté à l'iostrument. . . . Les honorables savants .uxquels je m'etais adressé penserent qu'il serait trop difficile de soustraire l'instrument ì diverses causes d'erreurs."

From the above, which was written twenty-three years ago, it is clear tlat to the eminent botanist must be accorded the merit of priority not only of the suggestion but also of the publication of the idea of the method of a veraging temperatures by observa. tions of the penclulum, while to Mir. Stanley must be given the credit of embodying that idea in a practical form and construcling an instrument based upon the principle.

st. Leonards-on-Sea, March 16

Conrad W. Cooke

\section{The Wasp and the Spider}

I HAD anticipated in my own mind Mrs. Hubbard's suggestion, and only the great pressure on your space prevented my meeting it in my previous letter. In the first place, my recollection is that the spider was of a kind that spins no web; like our own grey hunting spider, familiar in the summer on walls and palings. In the next place no species of spider, except the gossamers, habitually leaves this fine line behind it. It is in all cases a voluntary act, preceded by a perceptible pause, and pressure downwards of the extremity of the body to attach the end, whether for suspension, or in the process of forming the web. Even the gossamers are no exception to this rule; only in their case the line, in summer and autumn, is more continuously run out as a point of departure for their mysterious aërial flights. A house-spider, for instance, as he runs across the floor or across your hand, leaves no fine line behind him. The tiny gossamer has an amazing command of the material, but in the larger, webspinning kinds it is far from inexhaustible, and, at all events, an apparen:ly useless waste is not in the ordinary economy of nature. Moreover, in the case in question the spider was keenly aware he was pursued, and would not willingly leave so fatal a clue on his track. Mr. Merlin, who is on the list for 1878 as our consul for the Pireus, is, however, a competent observer, and could settle the question.

Bregner, Bournemouth, March 2.3

\section{SUN-SPOTS ANI) RATNFALL}

$\mathrm{BY}$ the overland mail which arrived here on January I2, I reccived, through the courtesy of Dr. W. W. Hunter, two copies of a pamphlet on "The Cycle of Drought and Famine in Southern India," a copy of the Nineteenth Cintury for November, and a copy of a letter on "The Rainfall in the Temperate 7one in Connection with the Sunspot Cycle," published in NATURE (vol, xvii. p. 59).

Having previously read notices of the pamphlet and being desirous to see it, I requested its author to favour me with a copy. His rainfall cycle for Matras was, so far as I could learn from newspaper reports, identical with a cycle which I had discovered long before. In my official report for 1875 , which was printed and circulated in 1876 , I gave a resumi of the results at which I had arrived from 1872 down to the close of 1875 , and stated that an examination of returns from 144 stations in different parts of the world, as well as of the variations in the levels of European rivers, had led me to the conclusion that there was a rainfall cycle of the same duration as the sunspot cycle and nearly coincident with it, both the sunspots and the rainfall attaining a minimum in the cleventh, first, and second years of the cycle, and a maximum in the fifti year. Hence when I learned from an abstract of 1)r. Hunter's results for Madras that in his "cycle of elcven years both the sunspots and the rainfall leach their minimum in the group consisting of the eleventh, first, and second years, and that both the rainfall and the sunspots there increase till they both reach their maximum in the fifth year," I was curious to know how his cycle had been made out; for although I had not the Madras rainfall for each year from I $_{13}$ to $18_{72}$, yet from the falls in the years of maximum and minimum sunspots which I got in the Procerdings and Thansactions of the Institution of Civil Engineers (vol. xxxii.), I inferred that the Madras rainfall was not quite so favourable to my hypothesis as the rainfalls of some other places. As, however, I might be wrong, I applied for a complete table of the Madras rainfall, but without success.

A rcmarkable rainfall cycle for Borbay, nearly coincident with the sun-spot cycle, had been reviously ascertained, and a simikr cycle, though not so well marked, had also been found by comparing the yearly mean rain. falls of Anjarakandy, Bombay, Calcuttr, and Nagpur with Wolf's relative sun-spot numbers.

I have now the whole history of the Madras cycle before me. The author of the pamphlet says that after many experiments he hit upon a method of working out a cycle. This method consisted in commencing with 1876 , taking backwards, as far as the register extended, periods of eleven years each, and then finding the mean rainfall for each series of years in the common period.

The results obtained for Madras by this method are to a considerable extent in conformity with those which I had found for different countrics; but there are discrepancies, one of the must remarkable of which is that the rainfall in the second year of Dr. Hunter's cycle is greater, instead of less, than the mean rainfall. Still there is a certain amount of coincidence. But as the method used by Dr. Hunter-and I would call special attention to this point-is different from the one by which I found my cycle, his results and mine are not comparable.

The sun-spot cycle being one of about eleven years, and the maximum epoch occuring, on an average, 37 years after the previous minimum, and the next minimum 7.4 years after the maximum, I found by experience that the best way of comparing the rainfall and the sun-spots was to start either from a maximum or a minimum year, and then to take the proper number of years before and after the epochal year. Commencing with a maximum year, for instance, I took five years before it and seven 
years after it, or thirteen years in all. Then, with of them, I then applied interpolation formulæ, and found the view of reducing the effects of the so-called non- a well-marked coincidence between the sun-spot and rainperiodic variations, I took a mean of the rainfall fall variations.

in the first and third of the thirteen. series, and a As the sun-spot cycles are not all of the same length, mean of that mean and of the rainfall in the second series, it is evident that by starting from any one year and going and so on. This gave me eleven new means, which backwards over a long period, always using the same fixed I called the "mean cycle." Again, starting with a mini- number, a maximum and a minimum year might fall into nimum year, I took eight years before it and four years" the same group.

after it, and found eleven other new means in the same Let me, by an example, explain my method more fully. way. To each set of results, or to a combination of both I take the Madras rainfall :-

Table I.-Rainfall Cycle at Mutrar.

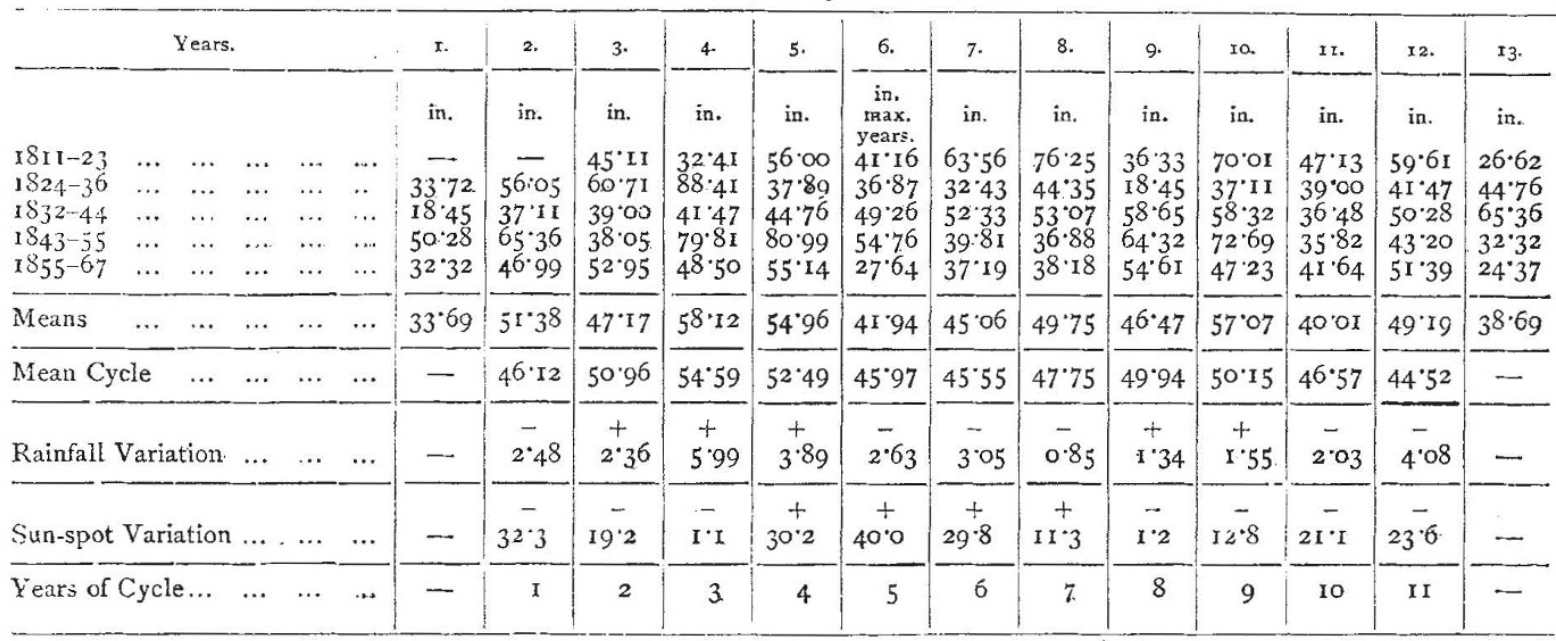

It will be seen that the individual years of maximum sunspots, I8I6, I829, I837, I848, and 1860 , are all in the same vertical column, and that all the years of minimum sun-spots, except 1810 , contribute to the formation of the beginning and end of the cycle. No doubt it would have been better to have placed 1836 . farther in advance, but this would have altered the position of the maximum year 1829 .

The results given by the above method show a double oscillation of the Madras rainfall during the sun-spot period, and I see (NATURE, vol. xvi. p. 333) that Mr. J. Allan Broun has found such an oscillation for Trevandrum as well as for Madras, and this may be a characteristic of the rainfall of the whole of Southern India. We have, however, evidence of a single rainfall oscillation for other parts of India. Even Mr. Blanford now admits that there is a periodic variation underlying all irregularities and more or less coincident with the sun-spot variation.

In consequence of the method adopted by Dr. Hunter the years of maximum sun-spots, in place of being all in the same group, are spread over three or four of the groups from which he derived his mean cycle, and it is probably owing to this that he missed what, I think, is the real character of the rainfall cycle at Madras, as shown in Table I. The annual average rainfall for each year of his cycle, together with the deviations from the mean, is as follows, and it will be seen that his cycle is very different from the one given by my method:-

\begin{tabular}{|c|c|c|c|c|c|c|c|c|c|c|c|}
\hline Years of Cycle. & s. & 2. & 3 . & 4. & 5. & 6. & 7. & 8. & g. & xo. & $x$ \\
\hline Average Rainfall $\ldots$ & $\begin{array}{l}\text { in. } \\
49^{\circ} \mathrm{x} 5\end{array}$ & $\begin{array}{c}\text { in. } \\
35^{\circ} \infty\end{array}$ & $\begin{array}{l}\text { in. } \\
49^{\circ} \circ 8\end{array}$ & $\begin{array}{c}\text { in. } \\
49^{\circ} 17\end{array}$ & $\begin{array}{c}\text { in. } \\
58 \cdot 33\end{array}$ & $\begin{array}{l}\text { in. } \\
50^{\circ} 95\end{array}$ & $\begin{array}{c}\text { in. } \\
50.37\end{array}$ & $\begin{array}{c}\text { in. } \\
54 \div 35\end{array}$ & $\begin{array}{c}\text { in.. } \\
52 \cdot 88\end{array}$ & ia. & $\begin{array}{c}\text { in. } \\
37^{\circ} \circ 3\end{array}$ \\
\hline Rainfall Variation ... & $0 .{ }^{+}$ & ${ }_{13} \cdot 31$ & $\stackrel{+}{\circ \cdot 77}$ & $\frac{+}{0.86}$ & $\stackrel{+}{10}$ & $\frac{+}{2 \cdot 64}$ & $\stackrel{+}{2 \cdot 06}$ & $\stackrel{+}{6: 04}$ & $\begin{array}{c}+ \\
4.57\end{array}$ & $\overrightarrow{3 \cdot 15}$ & $\underset{11 \cdot 28}{-}$ \\
\hline
\end{tabular}

According to Dr. Hunter's cycle, the rainfall of Madras was in excess in the fifth year to the extent of ten inches, whereas, according to mine, it was nearly three inches in defect. He takes, it is true, the years $1868-76$, which I do not take, preferring to wait till I get the rainfall of 1877 ; but although 1870 , which he puts down in his fifth group, was a very wet one, the double oscillation still exists, one of the minima occurring soon after the sunspot maximum.

I must now come to Dr. Hunter's letter in NATURE (vol. xvii. p. 59). But, first of all, I may be excused for saying that I do not think some remarks he made about a periodicity of cyclones in a former letter (vol. xvi. p. 455) were altogether calculated to put the matter in its proper light. He says (p. 456):-“M. Poëy called the attention of the French Académie des Sciences to the subject five years ago, and published, as far back as 1873 , a list of hurricanes in the West Indies from I 750 to 187.3 , in support of his views. Dr. Meldrum has worked the same question as regards the [East] Indian Ocean." Now if these words are meant to convey the impression that M. Poëy preceded me, and that I followed with the cyclones of the Indian Ocean, all I can say is that M. Poëy himself gave a different version of the matter.

In his second letter (vol. xvii. p. 59) Dr. Hunter states 
(I) that the evidence with respect to the European rainfall may be considered as "against a well-marked periodicity," and (2) that the result of a "systematic inquiry (by himself) into the American rain-returns altogether fails to establish the existence of a common cycle, so far as concerns the temperate zone." On each of these points I beg to make a few remarks.

The evidence on which Dr. Hunter bases his statement as to the European rainfall is derived ( $I$ ) from an examination by Mr. Baxendell, for a short period, of the rainfall at one English station, (2) from an examination by the late Dr. Jelinek of fourleen stations on the Continent, from 1833 to 1869 , and (3) from a comparison of the levels of the Elbe, Rbine, Oder, Danube, and Vistula, with the sun-spots for six cycles, a comparison which Dr. Hunter ascribes to Herr Gustav Wex, but which I believe is due to another.

Now, the evidence is much more extensive. Instead of being based on one British station and fourteen stations on the Continent, it is based on more than fifty British stations and more than forty stations on the Continent, and, taken with the evidence furnished by the rivers, it is, in my opinion, conclusive.

As to the American rainfall, an examination of thirtyfour returns has given me much more favourable results than those Dr. Hunter has got from twenty-two stations, and I have little doubt that he will, as he extends his investigations, also find favourable results ; but I think he must first adopt a method different from the one he used for Madras.

In support of my conclusion that the rainfalls of Europe and America are subject to a periodicity which closely corresponds with the sunspot periodicity, I will for the present only submit to your readers two tables, the one showing the general results for Great Britain, the Continent of Europe and America, and the other the results for one station in each of these countries, namely Edinburgh, Paris, and New Bedford.

TABLE II.-Comparison of the Variation in the Sun-spot Area with the Variations in the Rainfalls of Great Iritain, Continent of Europe, and Americat. from $\mathrm{IS2}_{4}$ to $\mathrm{SS6}_{7}$ inclusin?.

\begin{tabular}{|c|c|c|c|c|c|c|c|c|c|c|c|}
\hline Years of Cycle. & I. & 2. & 3. & 4. & 5. & 6. & 7. & 8. & 9. & 10. & II. \\
\hline 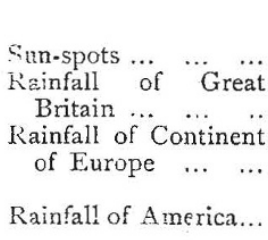 & $\begin{array}{c}- \\
3 \mathrm{I} \cdot 7 \\
- \\
2 \cdot 22 \\
- \\
0 \cdot 76 \\
- \\
2 \cdot 73\end{array}$ & $\begin{array}{c}- \\
19.5 \\
- \\
167 \\
- \\
1.73 \\
- \\
0.88\end{array}$ & $\begin{array}{c}+ \\
3.5 \\
+ \\
0.04 \\
- \\
1 \cdot 22 \\
+ \\
091\end{array}$ & $\begin{array}{c}+ \\
28.8 \\
+ \\
1 \cdot 16 \\
+ \\
0.44 \\
+ \\
0.53\end{array}$ & $\begin{array}{c}+ \\
39.5 \\
+ \\
1.05 \\
+ \\
1.18 \\
+ \\
0.24\end{array}$ & $\begin{array}{c}+ \\
29.5 \\
+ \\
1.46 \\
+ \\
0.97 \\
+ \\
1.34\end{array}$ & $\begin{array}{c}+ \\
10.4 \\
+ \\
1.28 \\
+ \\
1.08 \\
+ \\
2.03\end{array}$ & $\begin{array}{c}- \\
49 \\
+ \\
0.89 \\
+ \\
0.60 \\
+ \\
0.84\end{array}$ & $\begin{array}{c}- \\
14.8 \\
+ \\
0.43 \\
- \\
0.45 \\
- \\
0.27\end{array}$ & $\begin{array}{c}- \\
21 \cdot 2 \\
- \\
0.73 \\
- \\
0.36 \\
- \\
0.66\end{array}$ & $\begin{array}{c}- \\
19.4 \\
- \\
103 \\
+ \\
0.62 \\
- \\
1 \cdot 24\end{array}$ \\
\hline $\begin{array}{cccc}\text { Mean Rainfall Varia- } & \\
\text { tion } & \ldots & \ldots & \ldots\end{array}$ & $\frac{-}{1 \cdot 90}$ & - & - & $\begin{array}{l}+ \\
+ \\
0 \cdot 71\end{array}$ & ${ }_{0.82}^{+}$ & $\stackrel{+}{1 \cdot 26}$ & ${ }^{+} \cdot 46$ & $+\frac{+}{0 \cdot 7} \mathrm{~S}$ & $\overline{0}$ & - & $\overline{0.55}$ \\
\hline
\end{tabular}

The above results have been obtained in the manner in Great Britain the number of stations is 54, for the Conwhich I obtained the rainfall variation in Table I. For tinent of Europe, 42, and for America, 32 .

TABLE III.-Comparison of Variation in Sun-spot Area with Variations in Rainfalls of Edinlurgh, Prnis, and Neto Bedford, from 1824 to 1867 inclusive.

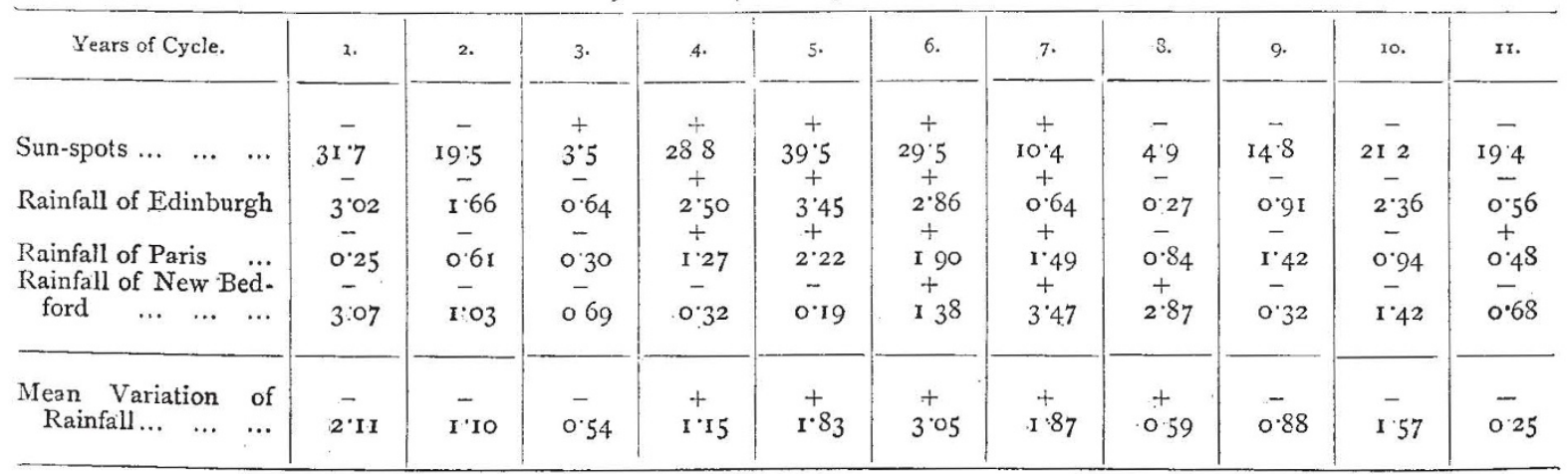

It will be observed (see Table I.) that the variation in the Madras rainfall is not nearly so favourable as the yariations for Edinburgh, Paris, and New Bedford.

What I have given here is but a small portion of the evidence in favour of a rainfall cycle. Having worked at

the subject for six years, I have concluded that the whole evidence is as satisfactory as the evidence of a connection between sun-spots and terrestrial magnetism.

Mauritius, February I
C. MELDRUM

\section{FULIUS ROBERT VON MAYER}

SEVERAL years ago (vol. v. p. II 7 ) we published a $\checkmark$ paper by Prof. Tyndall on the nature and value of Mayer's researches, in which they were so fully detailed
that now, on the occasion of the death of the man whose labours have won for him an undying renown, we need only briefly remind our readers of the chief events in his scientific career without entering into or attempting to renew a painful controversy of which it may be said that the truth lay neither wholly with one side nor the other. Julius Robert Mayer was born at Heilbronn, November 